\title{
Using Big Data for Sustainability in Supply Chain Management
}

\author{
Ricardo Chalmeta *(i) and José-Eduardo Barqueros-Muñoz \\ Grupo de Integración y Re-Ingeniería de Sistemas (IRIS), Departamento de Lenguajes y Sistemas Informáticos, \\ Universidad Jaume I, 12071 Castelló, Spain; joseduardobarqueros@msn.com \\ * Correspondence: rchalmet@uji.es
}

Citation: Chalmeta, R.; Barqueros-Muñoz, J.-E. Using Big Data for Sustainability in Supply Chain Management. Sustainability 2021, 13, 7004. https://doi.org/ $10.3390 /$ su13137004

Academic Editor: Alessio Ishizaka

Received: 8 May 2021

Accepted: 15 June 2021

Published: 22 June 2021

Publisher's Note: MDPI stays neutral with regard to jurisdictional claims in published maps and institutional affiliations.

Copyright: (C) 2021 by the authors. Licensee MDPI, Basel, Switzerland. This article is an open access article distributed under the terms and conditions of the Creative Commons Attribution (CC BY) license (https:/ / creativecommons.org/licenses/by/ $4.0 /)$.

\begin{abstract}
In the literature, several frameworks have been proposed to help sustainability management in supply chains. Nevertheless, they present a number of shortcomings. With the aim of overcoming these shortcomings, this paper proposes a framework for sustainable supply chain management composed of six dimensions: methodology, organization, stakeholders, maturity model, human resources, and technology. The main innovations of the framework are that (1) it includes a methodology that acts as a guide to sustainability management and improvement in a holistic way by using a balanced scorecard for any type of supply chain and covering the whole project life cycle; (2) it combines quantitative and qualitative methods for sustainability assessment; (3) it describes the techniques and technology to be used in each task of the methodology; and (4) it identifies the past impact of SC sustainability, as well as predicting its future impact, using Big Data analytics. The practical utility, completeness, and level of detail of the framework were validated through questionnaires answered by both five academics and three professionals. In addition, the framework was applied to a case study to (1) validate its usefulness and (2) to improve it with the feedback obtained.
\end{abstract}

Keywords: supply chain management; sustainability; balanced scorecard; Big Data; frameworks; stakeholders

\section{Introduction}

Sustainable development has become a key strategic objective worldwide since the definition of sustainability was formulated in the Brundtland report, according to which it is "development that meets the needs of the present without compromising the ability of future generations to meet their own needs" [1]. Sustainable development requires the consideration and integration of economic, social, cultural, political, and ecological factors in decision making, in an attempt to balance economic development, social development, and environmental protection [2]. As a result, the majority of large companies and an important number of small- and medium-sized enterprises have been incorporating policies and actions aimed at improving their sustainability. Likewise, they have also been communicating it among their internal and external stakeholders through annual sustainability reports, corporate websites, and different online and offline media [3].

However, in the context of an increasingly globalized world, where companies have been forced to associate to form Supply Chains (SC) in order to optimize resources and be more competitive, sustainability management requires a new approach. This new approach, forced by the pressure of stakeholders (such as investors, shareholders, customers, and nonprofits), is the so-called Sustainable Supply Chain Management (SSCM). Sustainability thus evolves from the internal perspective of companies to a supply chain perspective $[4,5]$.

The management and improvement of the three dimensions of sustainability (economic, social, and environmental) within the supply chain are complex tasks that involve different strategic, organizational, cultural, legal, human, and technological aspects. Although the supply chains are making efforts to infuse sustainability practices in their SC, they are struggling with their implementation. To solve this problem, different frameworks have been developed to help sustainability management in supply chains. 
However, existing frameworks (1) have a limited scope as they have been proposed for the individual needs of a specific industry or market sector; (2) they are focused on specific sustainability problems rather than adopting a holistic approach that enables them to improve the sustainability of the entire SC; (3) while some frameworks focus on the quantitative evaluation of the aspects of sustainability, others undertake a qualitative evaluation, and therefore, they do not take advantage of combining both methods; (4) they focus on the problems of sustainability assessment, without incorporating a methodology that describes how to integrate the results of quantitative or qualitative analyses with decision-making and action plans to improve the sustainability of the supply chain; (5) they describe what to measure but not how to measure the current impact and even less how to predict the future impact of the SC using the possibilities of new technologies such as Big Data.

Therefore, in spite of the usefulness of such frameworks, there are critical gaps in the field of sustainable supply chain management frameworks [6]. To overcome these shortcomings, in this paper, a framework called SSCM-IRIS is proposed, which facilitates the task of sustainability management in supply chains. The framework (1) includes a step-by-step methodology that describes the process of sustainability management and improvement in the supply chains of any sector by means of a holistic approach; (2) it combines both qualitative and quantitative methods for sustainability assessment; (3) it describes the techniques and technology to be used in each task of the methodology, as well as the stakeholders involved; and (4) it identifies the past sustainability impact of the SC, as well as predicting its future impact, by combining business intelligence tools with Big Data analytics. On the other hand, the framework allows the techniques proposed for the selection of indicators in the existing SSCM frameworks to be incorporated within a structured methodology. The earlier frameworks have many good points, and we wish to take advantage of this fact. The SSCM-IRIS framework is made up of six dimensions: methodology, organization, stakeholders, maturity model, human resources, and technology. The methodology of the framework covers the whole life cycle of the sustainable supply chain management and improvement project and defines how and where the tools of the other five dimensions can be used.

This paper is organized as follows: Section 2 shows the literature review related to sustainability and supply chain management, as well as a review of the existing frameworks proposed in the literature. Section 3 describes the SSCM-IRIS framework, which helps in the sustainability management and improvement of supply chains. Section 4 shows the procedure carried out to validate the framework. Finally, Section 5 discusses the SSCM-IRIS framework innovation and shows the conclusions, research limitations, and future work.

\section{Literature Review}

\subsection{Sustainable Supply Chain}

Globalization, the new possibilities to improve business management using computer information systems and tools, and the increasing pressure from customers for products with very competitive prices, high quality, great variety, short delivery times, and very good after-sales service have forced companies to rethink their relations with their stakeholders in the supply chain. A supply chain is a network of enterprises that collaborate during the whole life cycle of a product or service, interchanging products, services, information, and finances [7]. For this reason, the entire supply chain should be designed, managed, and coordinated as a unique organization. An adequate Supply Chain Management (SCM) must (1) optimize the interchange of information, goods, technology, knowledge, and services; (2) to improve the sustainability of each company and the whole supply chain [8]; and (3) train supply chain employees to continuously improve supply chain business processes [9]. Although SCM can be implemented in SC with a cooperative approach, there is usually a company in the SC, called the focal company, that governs the supply chain, provides direct contact with end customers; and has bargaining power over the other actors in the supply chain [10]. 
The main objective of SCM has been to achieve economic sustainability, based on the premise that an integrated and efficient supply chain helps to increase the benefits of all its members [11]. The social and environmental dimensions of sustainability, together known as the triple bottom line [12], have only recently begun to be considered in the SC, driven by increased societal and stakeholder pressures [13]. Markets and governments all over the world demand environmentally friendly products that prevent a decrease in the quality of life due to the exploitation of natural resources and pollution of the air [14]; green products are welcomed more than nongreen ones at the same price [15]; and customers and employees have become more committed to people's rights and a growing movement toward adopting social practices in the supply chain [16].

Therefore, there is a growing movement toward adopting social and environmental practices in the supply chain [17-19]. The objective is to achieve, in addition to the economic viability of the $\mathrm{SC}$ as a whole, social and environmental value that can benefit all the stakeholders in the SC and not only the shareholders [20]. This vision based on moral theories of sustainability aims to make supply chains truly adopt a moral commitment to society and the environment by bringing to the attention of all SC stakeholders, both internal and external, its social and environmental impact, and its intentions and objectives in this area. In this way, it is possible to audit and evaluate the level of real fulfilment of the SC sustainability objectives more easily, avoiding inconsistencies between the given message and the actions carried out [21]. It also makes it possible to avoid an instrumentalization of sustainability and to prevent achievement of economic benefits from marginalizing and prevailing over environmental and social objectives [22].

Therefore, one of the main challenges in SCM today is the integration of sustainability principles in the supply chain, considering a multidimensional (the economic, environmental, and social impact) and multiscale approach (institutional, geographical, and temporal) beyond the boundaries of the supply chain [23]. There must be an alignment between sustainable practices and organizations' strategies and capabilities to satisfy stakeholders' requirements [24,25]. This is where the so-called Sustainability Supply Chain Management (SSCM) concept appears.

\subsection{SSCM Frameworks}

The diversity of products and services provided by the supply chain [26], the geographical dispersion of the members of the supply chain with different legal regulations [27], the necessity to measure the impacts of the supply chain upstream and downstream [28], and the difficulty to obtain data beyond the supply chain [29] are the main obstacles hindering effective SSCM. Therefore, SSCM needs methods, tools, models, and frameworks to help managers in the decision-making processes [30]. In order to help overcome these challenges, different frameworks for SSCM have been proposed in the literature. These frameworks are mainly novel, which highlights that this field is new. A framework describes relationships between components, concepts, processes, data flows, aspects, or features for certain domains to achieve a specific objective [31]. Frameworks are made up of (usually interrelated) dimensions.

Existing SSCM frameworks are mainly oriented toward the assessment of corporate sustainability using quantitative approaches based on indicators or qualitative approaches. The majority of these frameworks are mainly novel and have been mainly developed by academicians, which highlights that this field is new and the existing frameworks for other domains have pitfalls. Different sustainability aspects are considered by the existing SSCM frameworks, although each framework only focuses on a few and there are none that cover all of them [6]. These aspects are: regulatory pressures/legal requirements; risk management; information transparency; green purchasing; environmental management; supply chain collaboration; eco-innovation; stakeholder pressure; corporate strategy; sustainable product design; customer management; competitiveness; standardization; supplier evaluation; supply chain; social responsibility; communication; certification; supply chain integration; health and safety; data and knowledge; collaboration with suppliers; supply 
chain performance; sustainable process management; sustainable supply management; supplier sustainability; global dispersion; financial; material; environmental supply chain strategy; reverse supply chains government; industry associational competitors; cost pressure; market position; corporate sustainability performance; learning; organizational size; customer; green manufacturing; incentive alignment; firm sustainability; organizational development; economic risks and disruption; waste; corporate policies; high degree of complexity; natural resources; energy efficiency; human capabilities; organizational integration; employee; society; nongovernment organizations, consumption and production patterns; training; rewards; supply chain reconceptualization; key performance indicators; supplier; commitment; economic performance; ecological performance; and transparency and resource efficiency.

Different studies prove that existing SSCM frameworks have various important weaknesses to be addressed, and therefore, there is room for new proposals. In sum, the main shortcomings of the proposed frameworks can be summarized as follows:

(1) They have limited scope, as they have been proposed for the individual needs of a specific industry or market sector. There is no generic framework for SSCM that can be apply to all kind of industries, and it is necessary to develop one that can be applied across all sectors [6,30].

(2) They are focused on solving specific aspects instead of adopting a holistic approach that allows them to boost the economic, environmental, and social performance of the supply chain [32].

(3) While some frameworks focus almost exclusively on the selection of indicators, others value only qualitative aspects to determine whether an SC has a coherent orientation toward sustainability. Therefore, they do not take advantage of the possibilities of combining both methods [6].

(4) They lack a methodology that specifies which tasks must be carried out, who should carry them out, which stakeholders should be involved, what technological system must be implemented to support the qualitative and quantitative analyses, and how to integrate the results of these analyses in decision making to improve the sustainability of the SC. The SC sustainability assessment should serve to optimize resources, improve processes, enhance product innovations, reduce costs, reinforce productivity, and promote SC values [33].

(5) They do not describe how to use the possibilities of the new information and communications technologies such as Big Data Analytics (BDA) to generate information and relevant knowledge about the current and future sustainability performance of the SC from structured data and nonstructured data sources [34,35]

(6) The lack of verified Sustainable Supply Chain Management (SSCM) frameworks, which raises a serious question on their applicability and has become a concern for the practitioners [36].

\subsection{Big Data and Sustainable Supply Chains}

Over the last few years huge amounts of data have been (and will continue to be) generated from different sources such as Internet of Things devices, social media platforms, web applications, enterprise internal information systems, etc. These very large data sets, known as Big Data, are defined by 7 V's: Value, the processed data generate information and knowledge to support decision making; Volume, very big amount of data; Velocity, data are created, stored, and processed in real time; Variety, data are stored and processes in different ways, types, and sources; Variability, data keep on changing constantly; Visualization, data can be presented in many ways to the management for decision-making purposes; and Veracity, degree of reliability of the information obtained [37].

Big Data Analytics are a set of tools, algorithms, simulations, and optimizations that can be applied to Big Data in order to analyze them and to extract unknown, hidden, valid, and useful relationships, patterns, and information [38]. This process allows organizations to gain business insights [39-43], to guide decision making, to be more productive, and 
to produce a competitive advantage for companies [44]. BDA can be classified in three areas: descriptive, predictive, and prescriptive. Descriptive BDA, such as online analytical processing (OLAP), is used to identify current problems and opportunities; predictive BDA focuses on discovering explanatory patterns using techniques and tools such as text and data mining, sentiment analysis, pattern recognition techniques, natural language processing, machine learning, and other artificial intelligence algorithms, etc., to identify future trends; and prescriptive BDA uses mathematical algorithms to assess alternative decisions [45].

Different studies have shown that BDA has a positive impact on helping organizations to achieve social dimensions and economic benefits, while minimizing the environmental impacts [46,47]. Therefore, Big Data is an essential tool in supply chain management and will enable the development of sustainable supply chains in the future [48]. In fact, insufficient Big Data Analytics capabilities and lagging behind the current trend in Big Data technologies are considerable barriers to sustainable supply chains.

BDA allows one to collect and organize supply chain data from heterogeneous systems distributed across organizational boundaries, analyze it, and visualize it intuitively to create a proactive supply chain system and to support decision making (. BDA are being used in different aspects of SCM such as to increase competencies and provide new capabilities [49], to support world-class sustainable manufacturing [50], to predict the supply chain and organizational performance [51], to improve flexibility in supply chain networks [52], to reduce costs [53], to design sustainable ship routing and scheduling [54], or to assess environmental efficiency [55].

BDA may be very useful for enhancing supply chain sustainability [56]. However, practitioners have problems of how to connect sustainability and Big Data, especially in supply chain management [45]. These problems can be synthetized in (1) a lack of knowledge on integrating BDA with supply chain business processes and systems to extract value; and (2) supply chain managers overlooking organizational aspects of BDA, focusing on technological issues, and ignoring its requirements and strategic role, which leads to ineffective BDA adoption [57].

Therefore, research investigating the link between sustainability and BDA as well as supporting the decision-making process of supply chain managers is necessary [58-60].

\section{SSCM-IRIS Framework}

In this context, the IRIS (acronym of Integration and Re-Engineering) research group at the University Jaume I (Castellón), has developed the Sustainable Supply Chain Management framework (SSCM-IRIS) to support the sustainability project and the decision-making process to achieve a sustainable supply chain using BDA and the balanced scorecard. The framework was developed taking into account the findings of the literature reviewed performed, because we want to take advantage of methods, tools, etc., proposed in the literature and the experience of the IRIS group members both as researches in the development and implementation of frameworks and methodologies to support managers to innovate in their organizations (some of them related with supply chains or the use of balanced scorecard for business sustainability management) as well as their experience as managers in companies.

The proposed framework is composed of six interrelated dimensions, which are (Figure 1): methodology, organization, stakeholders, maturity model, human resources, and technology. The main dimension of the SSCM-IRIS framework is the methodology, which guides during the different tasks involved in the sustainability management of supply chains. This methodology consists of phases, activities, and tasks. The remaining five dimensions consist of different techniques, methods, and tools, which support each task of the methodology. Therefore, in contrast to the other frameworks discussed in this paper, the SSCM-IRIS framework does not focus only on sustainability assessment but also pays attention to all the aspects (human, technical, or technological, for example) required for the correct integration of sustainability in SCM. 


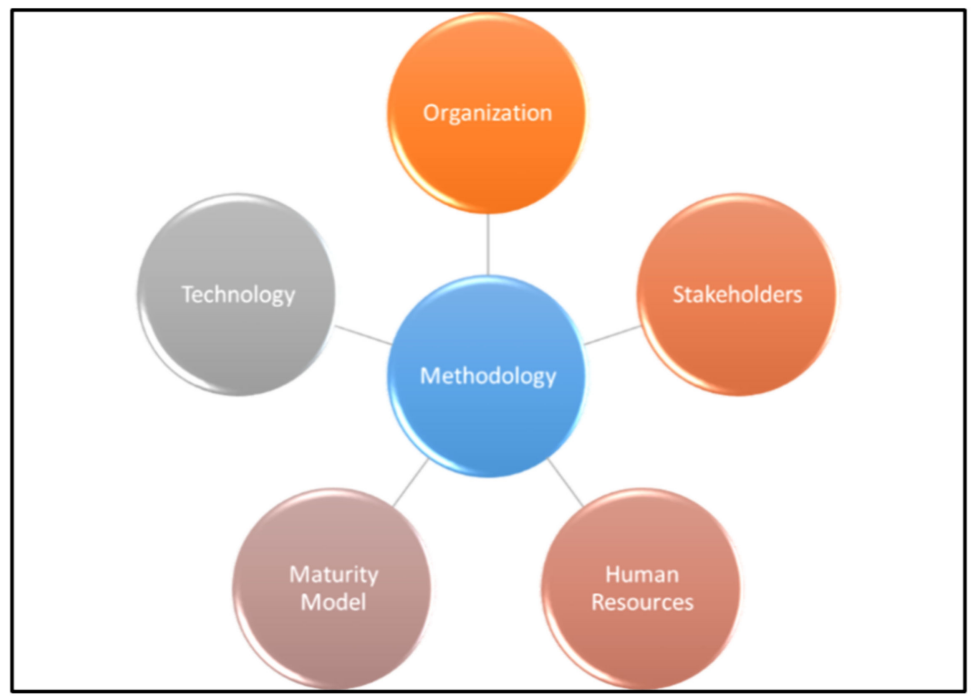

Figure 1. Dimensions of the SSCM-IRIS framework.

The SSCM-IRIS framework has been designed for SCs with a focal enterprise. If there is no focal company in the SC, its role can be assumed by one of the SC companies, which takes the initiative, or the decisions can be taken by mutual agreement among the different partners. The completeness of the framework, its practical utility, and its level of detail were validated through questionnaires answered by both academics and professionals who are experts in supply chains and in enterprise sustainability and through a case study. The SSCM-IRIS framework dimensions are explained below.

\subsection{Methodology}

The first dimension of the SSCM-IRIS framework is a methodology that defines the phases, activities, and tasks that should be carried out to achieve the sustainability management of the supply chain. In addition, the methodology identifies the support that other dimensions of the framework offer to the development of the different tasks. Tables 1-6 show the activities and tasks of the six phases of the methodology (Phase 1: Project Plan, Phase 2: Vision Statement, Objectives and Strategy; Phase 3: Quantitative Evaluation; Phase 4: Technological Implementation; Phase 5: Validation and Analysis of Results; and Phase 6: Improvement Actions), along with the support that the other framework' dimensions offer to the execution of these activities and tasks. The details of this support are explained in the following sections.

Table 1. Activities and tasks of Phase 1: Project Plan and support of other framework' dimensions.

\begin{tabular}{|c|c|c|}
\hline Activities & Tasks & Related Dimensions \\
\hline Feasibility Study & $\begin{array}{l}\text { Analysis of the financial, organizational, } \\
\text { operational, and technological project viability }\end{array}$ & $\begin{array}{l}\text { Human Resources: FI and PMO } \\
\text { Stakeholders: internal to the focal enterprise }\end{array}$ \\
\hline Project Plan development & $\begin{array}{l}\text { Commitment of the managers of the SC and } \\
\text { members of the SC } \\
\text { Definition of timeframe and sequence of the } \\
\text { project's activities } \\
\text { Definition of quality control mechanisms }\end{array}$ & $\begin{array}{l}\text { Human Resources: MSC and PMO } \\
\text { Stakeholders: internal to the focal enterprise } \\
\text { and the SC }\end{array}$ \\
\hline Definition of project's responsibilities & $\begin{array}{l}\text { Creation of the project teams } \\
\text { Evaluation of team's knowledge about } \\
\text { sustainability } \\
\text { Selection of team leaders and assignment of } \\
\text { their responsibilities } \\
\text { Schedule of follow-up meetings and training } \\
\text { program implementation }\end{array}$ & $\begin{array}{l}\text { Human Resources: HRM, PMO, and SSCMT } \\
\text { Stakeholders: internal to the focal enterprise } \\
\text { and the SC }\end{array}$ \\
\hline
\end{tabular}


Table 1. Cont.

\begin{tabular}{|c|c|c|}
\hline Activities & Tasks & Related Dimensions \\
\hline Development of Project Communication Plan & $\begin{array}{l}\text { Make the project known to all the SC internal } \\
\text { stakeholders, stressing that the project will } \\
\text { have a positive effect on the SC by making } \\
\text { both the SC and the SC members more } \\
\text { competitive and sustainable } \\
\text { Explain how the SC companies are going to } \\
\text { be affected }\end{array}$ & $\begin{array}{l}\text { Human Resources: SSCMT, HRM, and PMO } \\
\text { Stakeholders: internal to the focal enterprise } \\
\text { and the SC }\end{array}$ \\
\hline
\end{tabular}

Table 2. Activities and tasks of Phase 2: Vision Statement, Objectives, and Strategy and support of other framework' dimensions.

\begin{tabular}{lll}
\hline \multicolumn{1}{c}{ Activities } & \multicolumn{1}{c}{ Tasks } & \multicolumn{1}{c}{ Related Dimensions } \\
\hline Qualitative evaluation of SC companies & $\begin{array}{l}\text { Interviews with managers of the } \\
\text { companies in the SC } \\
\text { Interviews with heads of department } \\
\text { Survey through online questionnaire } \\
\text { for other employees }\end{array}$ & $\begin{array}{l}\text { Human Resources: MSC, ESC, and SSCMT } \\
\text { Stakeholders: internal to the focal } \\
\text { enterprise and the SC } \\
\text { Technology: Application web } \\
\text { Maturity Model: questionnaires and } \\
\text { interviews }\end{array}$ \\
\hline Definition of SC sustainability objectives & $\begin{array}{l}\text { Senior managers of the companies in } \\
\text { the SC at meetings with the SSCM team }\end{array}$ & $\begin{array}{l}\text { Human Resources: MSC and SSCMT } \\
\text { Stakeholders: internal to the focal } \\
\text { enterprise and the SC }\end{array}$ \\
\hline Selection of external stakeholders & $\begin{array}{l}\text { Selection of external stakeholders based } \\
\text { on the objectives }\end{array}$ & $\begin{array}{l}\text { Human Resources: MSC and SSCMT } \\
\text { Stakeholders: internal to the focal } \\
\text { enterprise and the SC }\end{array}$ \\
\hline $\begin{array}{l}\text { Selection of the sustainability strategy of } \\
\text { the SC }\end{array}$ & $\begin{array}{l}\text { Senior managers of the companies at } \\
\text { the SC meetings with the SSCM team } \\
\text { and SC stakeholders }\end{array}$ & $\begin{array}{l}\text { Human Resources: SSCMT } \\
\text { Stakeholders: all }\end{array}$ \\
\hline
\end{tabular}

Table 3. Activities and tasks of Phase 3: Quantitative Evaluation and support of other framework' dimensions.

\begin{tabular}{|c|c|c|}
\hline Activities & Tasks & Related Dimensions \\
\hline $\begin{array}{l}\text { Sustainability Balanced Scorecard } \\
\text { (SBSC) development }\end{array}$ & $\begin{array}{l}\text { Definition of objectives, goals, and indicators for } \\
\text { level } 1 \text { (economic, social, and environmental) } \\
\text { and level } 2 \text { dimensions (internal stakeholders, } \\
\text { external stakeholders, departments/business } \\
\text { processes, and resources). } \\
\text { Definition of objective cause-and-effect } \\
\text { relationships and indicators of cause-and-effect } \\
\text { relationships } \\
\text { Strategic map design } \\
\text { Assessment and validation with interviews and } \\
\text { questionnaires for the top managers of the SC } \\
\text { companies and external stakeholders }\end{array}$ & $\begin{array}{l}\text { Human Resources: MSC and SSCMT } \\
\text { Stakeholders: all } \\
\text { Technology: Application web/Form } \\
\text { Maturity Model: questionnaires and } \\
\text { interviews, SBSC }\end{array}$ \\
\hline $\begin{array}{l}\text { Allocation of weights and } \\
\text { definition of the sustainability } \\
\text { index to measure level of maturity }\end{array}$ & $\begin{array}{l}\text { Selection of panel of experts } \\
\text { Designation of the number of rounds } \\
\text { Definition of interview structure in each round } \\
\text { Definition of weights for each indicator } \\
\text { Definition of the sustainability index }\end{array}$ & $\begin{array}{l}\text { Human Resources: MSC and SSCMT } \\
\text { Stakeholders: all } \\
\text { Technology: Application web/form } \\
\text { Maturity Model: Method Delphi, } \\
\text { sustainability index }\end{array}$ \\
\hline
\end{tabular}


Table 4. Activities and tasks of Phase 4: Technological Implementation and support of other framework' dimensions.

\begin{tabular}{|c|c|c|}
\hline Activities & Tasks & Related Dimensions \\
\hline Design & $\begin{array}{l}\text { Functional, technological and graphic design } \\
\text { Identification of data sources, procedures to } \\
\text { extract data and calculate each indicator, } \\
\text { language, format of the data, periodicity, } \\
\text { norms of conduct, standards of development, } \\
\text { etc. } \\
\text { Ontology development }\end{array}$ & $\begin{array}{l}\text { Human Resources: PMO, ITD, and SSCMT } \\
\text { Stakeholders: internal to the focal enterprise } \\
\text { and the SC } \\
\text { Technology: BD-IRIS Framework }\end{array}$ \\
\hline Select technology tools and suppliers & $\begin{array}{l}\text { Hardware requirements } \\
\text { Selection of BI (ETL, DWH, OLAP, etc.), Big } \\
\text { Data and visualization tools } \\
\text { Selection of suppliers for installation, training } \\
\text { and/or consultancy }\end{array}$ & $\begin{array}{l}\text { Human Resources: PMO, ITD, and FI } \\
\text { Stakeholders: internal to the focal enterprise } \\
\text { Technology: BD-IRIS Framework }\end{array}$ \\
\hline DWH-SSCM development & $\begin{array}{l}\text { Software installation } \\
\text { Design of the design architecture } \\
\text { Implementation of the DWH }\end{array}$ & $\begin{array}{l}\text { Human Resources: PMO and ITD } \\
\text { Stakeholders: internal to the focal enterprise } \\
\text { Technology: ETL/DWH } \\
\text { Technology: BD-IRIS Framework }\end{array}$ \\
\hline $\begin{array}{l}\text { Software development for measurement of } \\
\text { indicators }\end{array}$ & $\begin{array}{l}\text { Software installation } \\
\text { Develop and/or parameterize the appropriate } \\
\text { software for calculating the current value of } \\
\text { the indicators, and its predictive analysis, } \\
\text { using the BI and Big Data tools }\end{array}$ & $\begin{array}{l}\text { Human Resources: PMO and ITD } \\
\text { Stakeholders: internal to the focal enterprise } \\
\text { Technology: Big Data } \\
\text { Technology: BD-IRIS Framework }\end{array}$ \\
\hline Data visualization & $\begin{array}{l}\text { Software installation } \\
\text { Parameterization in the form of dashboards, } \\
\text { reports, etc. } \\
\text { Verification and validation (User Acceptance } \\
\text { Test) }\end{array}$ & $\begin{array}{l}\text { Human Resources: PMO, ITD, SSCMT, and } \\
\text { MSC } \\
\text { Stakeholders: internal to the focal enterprise } \\
\text { Technology: BD-IRIS Framework }\end{array}$ \\
\hline
\end{tabular}

Table 5. Activities and tasks of Phase 5: Validation and Analysis of Results and support of other framework' dimensions.

\begin{tabular}{cll}
\hline \multicolumn{1}{c}{ Activities } & \multicolumn{1}{c}{ Tasks } & \multicolumn{1}{c}{ Related Dimensions } \\
\hline & Get the value of each indicator & Human Resources: SSCMT, MSC and FI \\
& Diagnostic analysis & Stakeholders: internal to the focal \\
enterprise and the SC
\end{tabular}

Table 6. Activities and tasks of Phase 6: Improvement Actions and support of other framework' dimensions.

\begin{tabular}{cll}
\hline \multicolumn{1}{c}{ Activities } & \multicolumn{1}{c}{ Tasks } & \multicolumn{1}{c}{ Related Dimensions } \\
\hline & $\begin{array}{l}\text { Definition and prioritization of sustainability } \\
\text { improvement projects }\end{array}$ & \\
& $\begin{array}{l}\text { Communication of the affected chain to the companies } \\
\text { and to external stakeholders }\end{array}$ & \multicolumn{1}{c}{$\begin{array}{l}\text { Human Resources: SSCMT, MSC, FI and HRM } \\
\text { Improvement actions }\end{array}$} \\
& $\begin{array}{l}\text { Training in SSCM for staff and heads of department } \\
\text { Implementation of sustainability improvement projects }\end{array}$ & $\begin{array}{l}\text { Stakeholders: all } \\
\text { Organizational: SCI-IRIS methodology }\end{array}$ \\
& $\begin{array}{l}\text { Share resources and information of SSCM practices } \\
\text { among the members of the SC } \\
\text { Establish control mechanisms }\end{array}$ & \\
\hline
\end{tabular}

The steps of the methodology are based on the Deming Cycle, also known as the PDCA (Plan-Do-Check-Act) cycle, which proposes a process for continuous quality improvement and is widely used in management systems. It is a management philosophy that seeks excellence from a continuous process of improvement [61]. On the other hand, the participative process of different stakeholders in phase 2: Vision Statement, Objectives and Strategy is based on the Back Casting methodology, which is considered a best practice 
in long-term planning in sustainability transitions [62]. Other activities and tasks are based in the experience of the authors in the development of frameworks and methodologies to innovate in organizations (see for example [63,64].

The tasks can be carried out sequentially (as in the waterfall mode) or in an iterative way. In this case, the whole project can be split into different parts, for example different areas of sustainability. Then, each part is carried out following the waterfall mode, and each part begins when the previous part has finished.

If there is a focal company in the SC, the scope of the project depends on the current level of sustainability of the focal company and its future vision, which can be truly sustainable or only sustainable in certain areas. It is foreseeable that truly sustainable focal companies will probably also try to achieve total sustainability in their supply chain. However, focal companies classified as sustainable only in certain areas could choose to remain in that status and proceed with the intention of ensuring that their supply chain is also classified as sustainable only in those areas. In this case, the determination of the stakeholders, mainly those external to the supply chain, the quantitative analysis of the current state, and the subsequent improvement actions, of both the focal company and its supply chain, focus only on those areas. For example, if a focal company aims to improve only its environmental sustainability, the external stakeholders would be environmental NGOs, academics, and professionals who are experts in environmental sustainability, etc. In the event that there is no focal company in the SC, its role can be assumed by one of the SC companies, or the decisions can be taken by mutual agreement among the different partners.

Once the qualitative and quantitative assessment of the supply chain has been carried out, one of the partners in the supply chain may have an unacceptable attitude toward sustainability and/or have an insufficient performance at a quantitative level. In this case, the focal company (or the rest of the members of the supply chain if there is no focal company) has two alternatives available to it. On the one hand, the focal company can decide on an inclusive strategy that involves helping the nonsustainable company, sharing sustainability information, tools and resources, and stimulating the implementation of sustainable improvement projects. On the other hand, the focal company can decide on an exclusionary strategy and replace this partner with another enterprise that meets the SC sustainability objectives and values.

\subsection{Human Resources}

The objective of this dimension is to identify all the Project teams-made up of employees from the SC companies - that will participate in the planning, execution, and decision making of the SSCM implementation project. The Project teams are as follows:

Managers of the SC (MSC). This group is composed of the top managers of the SC: CEO, department directors, and executive directors. Their participation will be decisive for the sustainability objectives and strategy statement, as well as for designing the sustainability balanced scorecard. Depending on the task, all of them or only the CEOs and executives will participate.

Employees of the SC (ESC). This group is composed of the other SC employees.

Project Management Office (PMO). The project management team will be responsible for planning and forecasting the feasibility of the SSCM project, as well as managing it by coordinating the different Project teams, technology providers, and other possible human resources external to the SC.

Finance (FI). The main function of this Project team will be to study the feasibility of the SSCM project in collaboration with the PMO team project, as well as to participate in the selection of suppliers from the financial point of view, and in the economic viability of the sustainability improvement projects.

Information Technology Department (ITD). This Project team will carry out the technological implementation of the SSCM by installing, developing, and parameterizing 
the database, ETL/DWH, Big Data, and visualization tools, as well as by providing the questionnaires and storing the results in a database.

The PMO, the FI, and the ITD Project teams will be made up of personnel from the focal company and, if necessary, by employees of other SC members. The ITD may have to be completed with people from outside the SC, depending on the tools selected and the knowledge that the people from inside the SC have of them.

Human Resources Managers (HRM). This Project team will consist of employees of the different Human Resources departments of the SC companies. Its main objective will be to evaluate the available human resources and look for the necessary resources inside or outside the SC to carry out the project. It will also be responsible for coordinating the training of the Project teams at the start of the project on SSCM issues, and the SC employees' training when the improvement actions are implemented.

SSCM Team (SSCMT). This is a multidisciplinary team made up of SC staff with experience, training, and/or an interest in sustainability and can be completed with people from outside the SC if the necessary profiles do not exist. The SSCM will be composed of a Project Manager (PM) to coordinate the available resources and to carry out the planning and execution of those tasks in which surveys and questionnaires are used; sustainability specialists to advise the MSC on matters of sustainability, to help to define the SC vision, strategy and objectives, to design the SBSC, or to execute different project activities such as qualitative evaluation; and communication specialists.

\subsection{Stakeholders}

Supply chain sustainable practices, strategies, and capabilities must be aligned to satisfy stakeholders' sustainability requirements. However, these requirements and the supply chain stakeholders can change due to the dynamic environment. For this reason, the participation of supply chain stakeholders is needed in different phases of the methodology. This dimension aims to identify all the stakeholders in the supply chain. According to [65], they are classified as internal and external stakeholders:

Focal company internal stakeholders: employees, executives, shareholders, and investors. They are involved in all the tasks, although in some tasks not all of them are involved.

Supply chain internal stakeholders: employees, executives, shareholders, and investors of the other SC companies. They are involved in all the tasks (although in some tasks only some of them participate), apart from the selection of technological tools, the development of the DWH-SSCM, and the development of the diagnostic and predictive software.

Supply chain external stakeholders: This category depends on the SC. Possible external stakeholders are final consumers, citizens, suppliers external to the SC, financial institutions, trade unions, overnment, local communities, media, competitors, academics and practitioners who are experts in the SC sector market, associations, and NGOs. They participate in the selection of the SC sustainability strategy (for example by assessing the suitability of an inclusive or exclusive strategy to improve the SC sustainability); Creation of the sustainability balanced scorecard, and definition of the sustainability index to measure the maturity level (academics, practitioners, representatives of NGOs, and public administrations, or experts in sustainability matters may be required to define the SBSC objectives and indicators or to define the allocation of weights); and improvement actions (the improvement actions carried out by the $\mathrm{SC}$ will be disclosed to them).

\subsection{Maturity Model}

The development of robust mechanisms for supply chain performance measurement have been identified as an integral step needed for the transition toward sustainable supply chain systems [66]. A maturity model defines objectives and indicators to identify at which level a system or company can be situated (within a certain area), and also a set of action plans to advance to a higher level of maturity [67]. The maturity model dimension of the SSCM-IRIS framework enables users to analyze the current situation and perform a diagnosis to identify sustainability problems as well as opportunities for improvement. The 
maturity model dimension is structured in three stages: qualitative assessment, quantitative assessment, and determination of the maturity level.

Qualitative assessment. The first step to improve SC sustainability is to know, through a qualitative assessment, what the vision of the focal company is as it regards to its own sustainability performance, as well as the SC sustainability performance. The result establishes where the SC stands, where it is actually going, the goals to be reached and the strategy to be followed, and the analysis of its culture, level of organization, and internal control. For example, it determines whether the scope includes all the three pillars of sustainability (economic, socialm and environmental) or just some of them.

In order to perform the qualitative assessment, two types of techniques are proposed: open-ended interviews and questionnaires. To get information directly from managers and employees of the SC, in the SSCM-IRIS framework, we propose the use of a semistructured interview. There are two types of semistructured interviews. On the one hand, we have semistructured interviews to the Board, whose goal is to identify their degree of responsibility and commitment regarding sustainability, as well as whether they are interested in pursuing the implementation of a total sustainability model within the SC or only a partial approach. On the other hand, we have semistructured interviews to Heads of Department, aimed at knowing the extent to which they have a clear understanding of the sustainability goals set by the executive board of the SC companies. Likewise, they are also designed to determine whether there is a well-defined corporate structure that supports the optimal achievement of these objectives. The questions regarding the degree of clarity of the goals can be more direct, while the questions regarding corporate structure could be combined with spontaneous questions, given the variety of aspects that can be approached (roles, communication, reward scheme, monitoring, etc.). Table 7 shows an example of the interview questions.

Table 7. Example of interview questions.

\footnotetext{
Semistructured interview questions to the Board
}

1. What is the vision of the Supply Chain regarding financial, environmental, and social sustainability?

2. Rate from 1 to 3 ( 1 being the highest) the relative importance that each aspect of sustainability has for the supply chain.

3. What actions are being taken in order to reach the SC sustainability objectives?

Semistructured interview questions to Heads of Department/Managers

1. Are you aware of your supply chain's vision regarding sustainability?

2. What are the supply chain's goals with regard to financial, environmental, and social sustainability?

3. Have the specific sustainability goals been well defined in your department/company/SC?

4. Does your department staff know what their sustainability goals are and how to reach them?

5. Are you aware of your role and your own goals in sustainability and how to reach them?

6. Have you ever been trained in sustainability?

7. Have your staff ever been trained in sustainability?

8. Is there a system that rewards employees who actively pursue the improvement of sustainability in the supply chain?

In addition, to find out how much the other SC employees know about the SC sustainability goals and the corporate structure provided by the SC to reach these goals, a questionnaire is administered with three possible answers: Yes (Y), No (N), Don't Know (DK). This questionnaire, besides confirming whether the goals are clear enough for all members of the SC, also identifies the coherence between the goals and the resources provided by the focal company and the other members of the SC.

Quantitative Assessment. The qualitative assessment must be complemented with a quantitative assessment. Insodoing, it is possible to accurately determine the level of sustainability of the SC, the necessary improvement actions related to every aspect of sustainability, and to follow up the degree of achievement of the planned goals once the improvement actions have been implemented. The quantitative assessment is able to answer questions such as the following: Have the actions to improve sustainability in the SC been defined and carried out properly? Will the SC sustainability goals be achieved in 
the near future? Will the SC level of sustainability improve if we keep the nonsustainable companies as a part of the SC? Will the SC level of sustainability improve if we replace those companies?

The quantitative analysis is based on a set of indicators that show the impact of SC sustainability and make it possible to verify to what extent the SC sustainability objectives have been achieved. Hence, the indicators must be aligned properly with the SC sustainability strategy and objectives. On the other hand, the indicators must be identified in an organized fashion. One of the most suitable methodological tools for this is the Sustainable Balanced Scorecard (SBSC) [68]. The SBSC is an evolution of the Balanced Scorecard [69], applied to the supply chain [70], which includes sustainability aspects [71]. The SBSC allows the identification of objectives and indicators taking into consideration different dimensions of sustainability (such as economic, social, or environmental), decisional levels (strategic, tactical, and operative), enterprise departments/business processes (marketing, finance, operations, store, production, purchases, administration, etc.), members of the supply chain (raw material provider, manufacturer, distributor, etc.), or stakeholders (employees, customers, public administrations, etc.). The SBSC has a hierarchical structure and identifies cause-and-effect relationships among objectives and indicators, which makes it possible to analyze the impact of SC sustainability and the sustainability impact of a specific member of the SC, or to descend down to the process or task level to identify those that fail to meet the desired standards of sustainability.

Figure 2 shows the structure of the SBSC proposed within the SSCM-IRIS framework for an SC. This SBSC has two levels. The top level has three perspectives that correspond to the three sustainability dimensions, and the bottom level has four perspectives that correspond to the internal stakeholders, external stakeholders, resources, and business processes/departments. First of all, economic, social, and environmental SC objectives are defined on the three decisional levels (strategic, tactical, and operative), together with indicators to measure their degree of achievement. Then, there is the bottom level, which defines the objectives and indicators for the four perspectives. Bidirectional linkages are defined among the perspectives inside each level, since all of them are considered to have the same importance for sustainability. For example, there can be financial objectives that can help to achieve social objectives and vice versa. The same happens among the perspectives on the bottom level. On the other hand, the objectives of the top level define the bottom level objectives, and the indicators of the bottom level are data that are used to calculate the top level indicators. A graph of these cause-and-effect relations should be created in an SBSC strategic map.

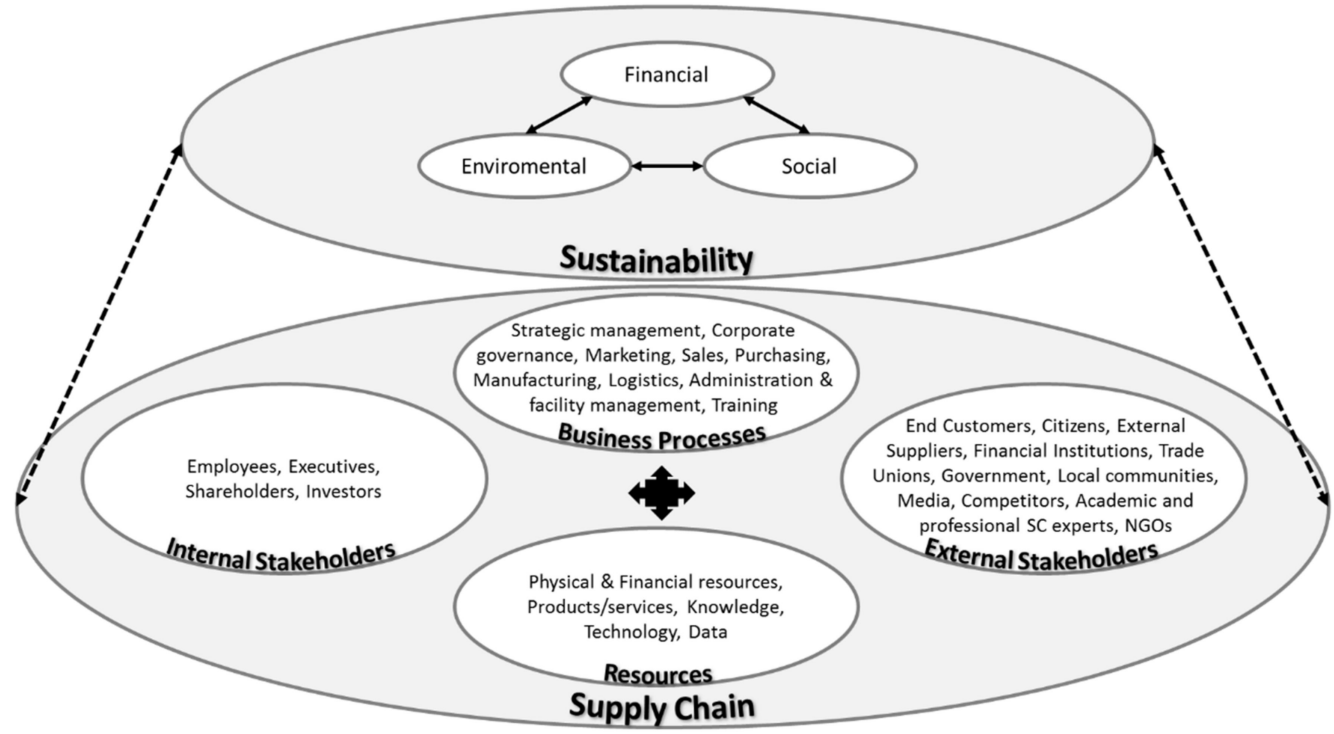

Figure 2. SBSC structure proposed for a supply chain. 
The definition of objectives and indicators within the SBSC depends on the SC activity market sector. The indicators proposed by international initiatives and organizations such as the Global Reporting Initiative (GRI) or the United Nations division for sustainable development can be taken as a reference. Furthermore, the SSCM frameworks proposed in the existing literature that include a set of indicators to measure specific aspects of sustainability can also be used. Choosing the indicators requires the collaboration of internal stakeholders from both the focal company and the rest of the SC members, as well as the external stakeholders such as representatives from NGOs, local associations, government, etc. This could be performed by means of a semistructured interview model.

Once the indicators have been selected, it is necessary to define the method of calculation, the related objectives, the unit to be used, the data that make it possible to obtain the indicators (they may be numerical data, documents, video, audio, text, posts, etc.), the data sources (both internal and external to the SC, and both tacit, such as employees, customers, etc., or explicit), how frequently the indicator must be calculated, and the form of presentation.

Unlike traditional balanced scorecards, the proposed SBSC does not focus on measuring only the past impact of SC sustainability from structured internal SC databases using business intelligence tools. Big Data analytical techniques are also used to extract value from unstructured data sources that are internal and external to the SC. Therefore, the SBSC can be used to extract unknown, hidden, valid, and useful relationships, patterns, and information that can be used to explore, discover, and predict the current and future impact of SC sustainability.

Maturity level. The quantitative assessment allows the global SSCM maturity level of the SC to be set (Table 8). To do this, it is necessary to define the weights of each indicator. Multiple methods have been proposed in the existing literature both to set the weights of the indicators and to calculate the sustainability index. We recommend the proposal by [72] because they use the Delphi method, which is well known and commonly accepted among the scientific community.

Table 8. SSCM maturity levels, based on the five levels of the theory of moral sustainability [21].

\begin{tabular}{ll}
\hline \multicolumn{1}{c}{ Level } & \multicolumn{1}{c}{ Description } \\
\hline Level 0: No sustainability & $\begin{array}{l}\text { None of the SC companies meet the sustainability levels in any of its } \\
\text { dimensions—financial, environmental or social. }\end{array}$ \\
\hline Level 1: Partially sustainable in specific areas & $\begin{array}{l}\text { Some of the companies in the SC have a good sustainability performance in one or } \\
\text { several of the dimensions of sustainability but not in all of them or in the } \\
\text { same dimensions. }\end{array}$ \\
\hline Level 2: Sustainable in specific areas & $\begin{array}{l}\text { All the SC companies have a good sustainability performance in one or several of } \\
\text { its dimensions. }\end{array}$ \\
\hline Level 3: Partially sustainable & $\begin{array}{l}\text { Some of the companies in the SC meet the sustainability goals in all its dimensions, } \\
\text { but other companies either fail to meet the goals in all the dimensions or do not } \\
\text { meet any of the goals at all. }\end{array}$ \\
\hline Level 4: Totally sustainable & $\begin{array}{l}\text { All the SC companies meet the sustainability goals in all its dimensions. Vision, } \\
\text { goals, corporate structure and employees are aligned to work to achieve a total } \\
\text { sustainability-financial, environmental, and social. }\end{array}$ \\
\hline
\end{tabular}

\subsection{Organizational}

Once the data to calculate the indicators have been collected, each indicator has been measured, and the SC sustainability index has been obtained, it is time to check whether the SC sustainability objectives are being achieved, by identifying the SC companies and processes that need to improve their sustainability performance. To perform this analysis, the Supply Chain Integration IRIS (SCI-IRIS) methodology [71] is used. This instrument allows for (1) the redefinition of the goals (mission, vision, and strategy) and culture (policy and values) of the whole SC and the SC members, by taking into account the 
findings of the qualitative evaluation of sustainability; (2) the re-engineering of internal and external SC business processes to achieve the sustainability goals. Throughout the redesigning of the business process, the current AS-IS SC sustainability impact identified in the quantitative assessment is taken into account, together with recognized standards such as ISO 9001, ISO/TS 16949, ISO 14001, EMAS, OHSAS 18001 regulations, etc.; (3) training in sustainability and the reorganization of human resources along the SC; and (4) the implementation of the improvements and monitoring of the outcomes. The result is the proposal of a set of medium and long-term SC sustainability improvement projects arranged in order of priority and aligned with the desired future sustainability situation (TO-BE). Traditional cost/benefit, social, environmental, organizational, technical, and operational aspects are considered to carry out a feasibility analysis and to establish the priority of projects.

The SC sustainability improvement projects may affect several companies in the SC, and they can have a strategic scope (for example, different scenarios regarding the SC structure can be simulated to establish where to locate the manufacturers so as to balance emission rates and labor and operating costs), a tactical scope, or an operational scope. At this point, the focal company can take two different approaches: active or passive. If it takes a passive approach, the focal company informs SC companies about their low-sustainability performance and gives them the opportunity to improve their sustainability index before the next assessment cycle. On the other hand, if the focal company decides on the active approach, it carries out actions such as:

Organizing joint meetings among the focal company, the affected companies, and external SC stakeholders to coordinate and implement the improvement actions.

The focal company could promote the sharing of knowledge on sustainability best practices with the SC companies.

Promoting training in sustainability for employees of the SC companies.

Stimulating positively (by agreeing long-term relationships with companies whose maturity level is 3 or 4 ) or negatively (by warning those companies with a maturity level of 0 or 1 about the possibility of them being replaced).

Finally, the focal company might choose to look for new partners that could improve the supply chain sustainability by replacing the questioned companies, if these companies have not applied the proposed sustainability improvement projects properly. The same indicators (and Big Data techniques) used in the SBSC to assess the SC companies can now be used to evaluate the new partners. This would make it possible to verify, for example, that in the past these new partners have not performed harmful practices that could damage the SC Brand.

\subsection{Technology}

In order to perform the quantitative assessment, it is necessary to develop a computer information system. This system is used to identify, extract, clean, store, process, and distribute the data needed to generate the indicators applied in the quantitative assessment. To build the computer information system, the SSCM-IRIS framework follows the steps recommended by the BD-IRIS framework for the implementation of a Big Data ecosystem in Companies [63]. These steps are: (1) Content. In this step, location, format, and the source of the data are identified, and the most significant specific data are selected. Sources can be structured, from internal relational databases of the information systems of the supply chain enterprises such as Enterprise Resource Planning (ERP), Customer Relationship Management (CRM), Supply Chain Management (SCM), etc., or from external relational databases, and may also be unstructured. These unstructured data sources can be internal to the supply chain (sensor data, internal Web 2.0 tools, e-mail messages, log files, machinegenerated data, transaction records, etc.), as well as external applications such as online social networks, websites, open data, wikis, GPS, etc. (2) Acquisition. In this step, data are obtained from their respective sources. Patterns, filters, and preprocessing methods are applied to raw data to transform them into an easily and effectively processable format. 
Different methods can be used, such as sampling (a representative subset is selected from a large data set), transformation (modifies the data to fit a particular type of input), denoising (eliminates the noise existing in the data), or normalization (organizes data to allow a more efficient access). On the other hand, to avoid semantic problems, it is essential that all supply chain members interpret the knowledge related with the supply chain sustainability in the same way. This semantic problems may appear due to the different background of the people involved in the supply chain decisions making such as finance, accounting, corporate governance, management, information systems, performance, etc., and the different language and cultural context. Therefore, their interpretation of concepts is not always identical. A solution for this is to develop an ontology of the sustainability knowledge domain of the supply chain. The ontology facilitates the knowledge search, discovery, and sharing [73]. (3) Enhancement. In this step, the collected data are endowed with value, by applying the transformations needed to calculate the sustainability indicators. When necessary, different BDA can be used. These BDA are applied to discover unknown relationships and patterns from structured and unstructured data. These techniques allow one not only to calculate the current sustainability impact of the supply chain, but they also allow one to predict the future sustainability supply chain behavior from historical and current data. Different artificial intelligence algorithms can be used to make predictions, such as logistic regression, random forest, and decision trees, among others. In addition, the metadata are also generated, which simplifies the execution of queries or operations. These new metadata, information, and knowledge are stored in a Sustainable Supply Chain Management Datawarehouse (DWH-SSCM) for diagnostic and predictive analyses that support the quantitative assessment and decision-making to improve the SSCM. (4) Inquiry. In this step, the data and metadata stored in the DWH-SSCM are accessed, mainly through queries using Structured Query Language (SQL). (5) Visualization. In this step, the results, including the interpretation of the meaning of the information that has been discovered, are shown to the users through dashboards, reports, alerts, etc.

The Sustainable Supply Chain Management Datawarehouse is implemented at the focal company. The DWH-SSCM stores all the data extracted from the different data sources that make it possible to obtain the values of the different indicators, as well as the information and knowledge generated. In the DWH-SSCM, there is always an updated copy (depending on the frequency of data refresh) of the data available in each of the data sources used. Data from semistructured and unstructured data sources cannot be managed efficiently by relational databases, since this requires building an index for unstructured data, balancing the data integrity and access efficiency, or storing data with flexible and variable structures. To deal with this problem, NoSQL and NewSQL databases can be used.

Apart from the technological implementation, another important question regarding this computer information system is that it deals with sensitive data. To manage such data, the focal company must consider the risks and its obligations when processing and distributing these data. In order to protect personal identification information, different methods such as anonymization, encryption, use of pseudonyms, encryption keys, or data dissociation could be used. On the other hand, different security actions should be taken into account, such as designing the system to identify and mitigate cyber threats or ensuring that the authentication of users is robust.

\section{SSCM-IRIS Framework Validation}

Once the framework had been developed, the next step was to validate and improve it. It consisted of two phases: expert assessment and a study case.

\subsection{Expert Assessment}

The practical utility, completeness, and level of detail of the framework were validated through questionnaires answered by both five academics and three professionals (one manager of a transport company and two belonging to a consulting company) with extensive experience in the field of supply chains and enterprise sustainability. The method used for 
the qualitative evaluation consisted of an initial presentation explaining the framework, and after that, the opinions of the experts were collected through interviews, which were individual, open (allowing any response), and semistructured (questions and were used as a script, but there was no established order, and improvisation was allowed by both the interviewer and the interviewee). The experts did not use the framework with a particular data set; instead, their opinions were based on their knowledge and experience.

Each of the interviews was carried out by a single interviewer, who interviewed all the experts. Each of the interviews lasted approximately $45 \mathrm{~min}$. Interviewees were asked about the framework utility, completeness, and comprehensibility; the adequacy of its structure and organization in six dimensions; the level of detail of the phases of the methodology; the accuracy of the relationship among the phases and activities of the methodology and the other dimensions; the mistakes they had encountered; and their suggestions for improving the framework. Professionals were also asked to compare and contrast the SSCM-IRIS framework with the heuristics procedures that they use in their companies to identify the main strengths and weaknesses of SSCM-IRIS framework. The interviewer took notes and wrote a report based on the interviewees' responses. Subsequently, each report was validated by the corresponding interviewee to avoid misunderstandings. The validated reports were analyzed individually by two researchers, identifying the strengths of the framework and studying both the weaknesses detected and the suggestions proposed to improve the framework.

Interviewees corroborated the framework as a useful tool for sustainability management in supply chains, acknowledging, with minor improvement suggestions, their utility, completeness, accuracy, level of detail, and comprehensibility. They highlighted the capacity of the framework to be applied to different kinds of supply chains; the holistic approached adopted; the inclusion of a methodology to guide during all the project life cycle; the level of detail in each phase of the methodology; the structure proposed to organize the SBSC objectives and indicators; the consideration of indicators obtained by the use of Big Data techniques; the proposal of a computer architecture to support the SSCM implementation; and the overall understanding of the project that the framework offers. On the other hand, the main shortcomings identified were: the lack of definition of quality control mechanisms; and the necessity of a prior evaluation of team's knowledge about sustainability. The framework was modified according to these experts' suggestions.

\subsection{Case Study}

After the experts' evaluation and improvement, the framework was applied to a case study to (1) validate its usefulness and (2) to improve it with the feedback obtained. A work plan based on [74] was followed, which consists of five phases: case study design and planning; preparation for data collection; collecting evidence; analysis of collected data; and calidation of collected data.

Case study design and planning. The aims of the case study are: (a) to validate the SSCM-IRIS framework by verifying and confirming its usefulness, accuracy, and quality, and (b) to refine and improve the framework developed initially from the experience acquired by the researchers, the feedback obtained from the company involved, and the conclusions drawn in the case study.

The research work was conducted over a period of 6 months. The first task was to select the company in which the case study was to be applied. The criteria underlying the selection of this company were essentially: (1) a willingness to collaborate in the research, and (2) the fact that the management of this company was considering the idea of operating in a zero-emission full-lifecycle supply chain. To do this, the company wanted to develop new, more sustainable, and efficient solutions for the mobility and transport sector, working in partnership with its customers and business partners. The selected company was a large international logistics company, a market leader in automotive logistics. The company has around 10,000 employees in several countries worldwide. Total income for 2018 was more 
than USD 4 billion. They operate more than 100 vessels servicing 15 trade routes to six continents, together with a global inland distribution network.

Preparation for data collection. To begin the research work, an introductory series of group interviews was held in the company. The presentation focused on both the basic points of a sustainability supply chain project and the explanation of the framework that was going to be used (initial version of the SSCM-IRIS framework).

In order to undertake all the research tasks during the application of the framework in the company, a mixed work team was set up with members that came from the IRIS research group and the company SSCM management team. The company SSCM management team was made up of staff members of the company such as the Vice Presidents of Sustainability, of Operations, and of Digital Transformation, as well as representatives of other companies of the supply chain internal stakeholders with some specific weight in their companies, such as the ship owner representative, the inland distribution representative, and the marine terminal representative. The purpose of the mixed work team was to be responsible for making decisions about all issues related to the project.

Collecting evidence. The data collected were the results of applying the different stages of the SSCM-IRIS framework's methodology to the company. According to the SSCM-IRIS framework's methodology, the application of the SSCM-IRIS framework followed this sequence: (1) the viability of the project was studied; the Project Plan was developed; the project's responsibilities were defined; a Project Manager was appointed as being responsible for the whole project management; and the Project Communication Plan was developed. (2) Through qualitative evaluation the supply chain strategy was defined. It was decided to consider the three pillars of sustainability (economic, social, and environmental). (3) A Sustainability Balanced Scorecard (SBSC) was developed, defining objectives and indicators to measure them, together with the location of weights and definition of the sustainability index to measure the supply chain sustainability level of maturity. Figure 3 shows a sample of the supply chain strategic map with objectives for level 1 (economic, social, and environmental) and level 2 dimensions (internal stakeholders, external stakeholders, departments/business processes, and resources), and their cause-and-effect relationships. Table 9 shows a sample of indicators to measure the objectives achievement. (4) the technological infrastructure to support the quantitative evaluation was designed and developed. A Datawarehouse was implemented to gather all the relevant data to calculate most of the operational and financial indicators (fuel consumption, speed, costs, revenues, etc.) from the computer systems (ERPs, CRM, SCM, etc.) of each member of the supply chain. In addition, a pipeline was implemented to gather external semistructured and unstructured data generated outside the company through web scraping from open-source social media sites such as Twitter and Facebook. These data allowed the company, for example, to know about the satisfaction of its customers, if its competitors had implemented or were developing sustainability initiatives, and the opinion of experts and the general public about its products and services. These sources were linked, and only the data that were useful to obtain the required indicators were collected using the appropriate filters and patterns. To process these data, different Big Data techniques were used. For example, sentiment analyses were used to extract and analyze the public's mood and views about a product/service. The Big Data tools used were a combination of a commercial data analytics software and some free-distribution software for customization purposes. (5) The indicators were obtained, and therefore, it was possible to determine the supply chain sustainability performance and its maturity level. (6) Finally, supply chain sustainability improvement projects were defined, prioritized, and implemented, such as:

- Vessel speed optimization

- Vessel consumption reduction

- Terminal capacity optimization

- Sustainable supply chain awareness global training 


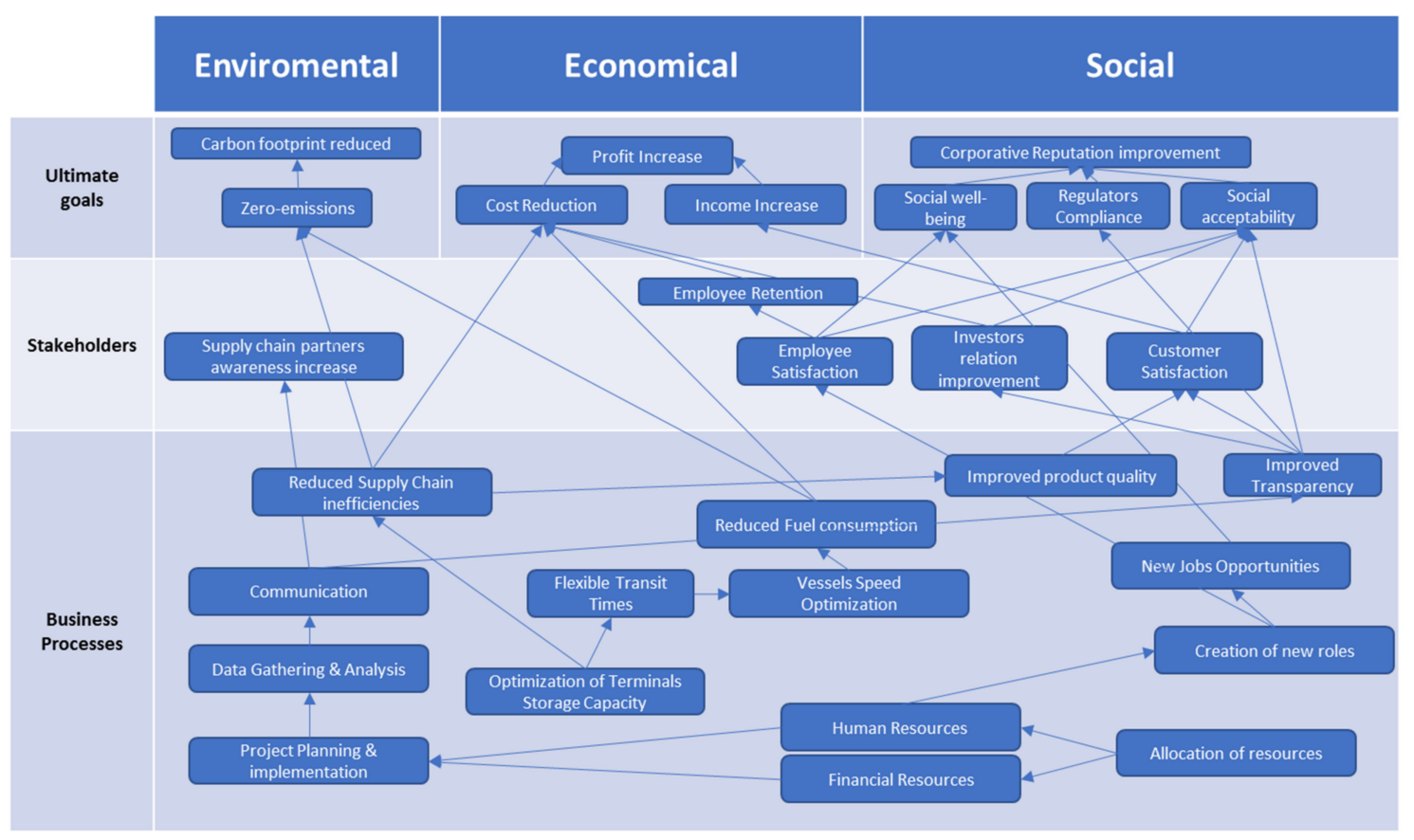

Figure 3. Example of the supply chain strategic map.

Table 9. Example of indicators to measure the objectives achievement.

\begin{tabular}{ccc}
\hline \multirow{2}{*}{ Perspective } & \multicolumn{1}{c}{ Indicator } & Units \\
\hline \multirow{3}{*}{ Environmental } & Carbon footprint decrease & metric tons of $\mathrm{CO}_{2} \mathrm{e}$ \\
\cline { 2 - 3 } & Fuel consumption reduction & Metric tons \\
\cline { 2 - 3 } Economical & Speed reduction & Knots \\
\cline { 2 - 3 } & Increase in profit & USD million \\
\cline { 2 - 3 } & Cost reductions & USD million \\
\hline \multirow{3}{*}{ Social } & Customer satisfaction survey & $0-10$ \\
\cline { 2 - 3 } & Employee satisfaction survey & $0-10$ \\
\cline { 2 - 3 } & Social media sentiment & Bad-Good \\
\hline
\end{tabular}

To collecting evidence about the results of applying the SSCM-IRIS framework's methodology to the company, qualitative data were used, which were collected through direct methods (using an assortment of questionnaires and templates) and independent methods (copies of the documents and reports used in the company). The questionnaires were answered by members of the company SSCM management team during individual interviews, once the implementation of each one of the phases that compose the SSCM-IRIS methodology had finished. It was done in this way to solve unforeseen problems and to consider improvement suggestions before starting the next phase. These interviews lasted approximately $20 \mathrm{~min}$ and were open (thus allowing interviewees to give a wide range of answers) and semistructured (the questions were planned only as a guide, not to be asked in that same order, thereby allowing both the interviewers and the interviewees to improvise). The aims of these interviews were: to analyze the execution of the phase; to obtain feedback about the experience and the observations of each manager in each phase; to detect errors; and to collect proposals for improvement to the SSCM-IRIS framework from each of them. There was a different questionnaire for each phase, and those questionnaires were common to all interviewees. 
Analysis of collected data. In this case, the analysis was inductive and was carried out parallel to the data collection, as it was performed after each of the stages that make up the SSCM-IRIS framework's methodology had finished. The purpose of this was to be able to react quickly to the assessments encountered during the analysis of each stage and thus rectify each one of them and take advantage of these improvements in the following stages. This analysis of collected data allowed for the improvement of the framework with the suggestions by modifying/incorporating/removing phases, tasks, tools, etc. Finally, the final version of the framework was validated with the general agreement of the SSCM management team.

As a result of the application of the SSCM-IRIS framework in the company, members of the company SSCM management team have pointed out that the SSCM-IRIS framework has enabled them:

- To obtain a good view of the project scope and consequences, as well as to improve the sustainability of the supply chain quickly and without serious problems

- To perfectly control the project, because all the activities to be carried out during the whole project life cycle were clearly defined, and the rest of the dimensions of the framework gave suitable support to the execution of these activities

- To achieve all the goals set out at the beginning of the project and to accomplishe the timespan initially established without significant deviations

- To clarify and update the strategy for the environmental, social, and economic sustainability of the supply chain, considering the situation of each enterprise that belongs to the supply chain

- To communicate the sustainable strategy throughout the supply chain members

- To align enterprises, unit, and individual goals with the supply chain sustainability strategy

- To link objectives to long-term targets and annual budgets

- To conduct periodic sustainability performance reviews to measure the sustainability objectives achievement and to develop actions plans to improve the supply chain sustainability.

- To generate new information using Big Data to measure the sustainability performance of the supply chain from structured and unstructured data sources, both internal to the supply chain and external.

Not all the comments were positive, but negative comments were considered to improve the methodology. Examples of these negative comments were the necessity of:

- Ensuring data security to avoid that different external stakeholders can access sensitive data.

- Involving more stakeholders in the different stages of the validation.

- Improving accuracy/communication of sentiment analysis method.

A comparison of the value of some indicators 8 months after the application of the SSCM-IRIS framework was performed (Figure 4). In this comparison, some significant improvements can be observed due to the implementation of action plans to improve the sustainability of the supply chain. The most significant are: carbon footprint decrease (7\%); fuel consumption reduction (9\%); speed reduction (4\%); increase in profit (6\%); cost reductions $(10 \%)$; increase in customer satisfaction (18\%); increase in employee satisfaction (32\%); and invoiced amount (13\%). On the other hand, it is important to take into account the costs required for implementing the framework at the company, because they affect the returns of the investment. These costs can be classified in three categories: Human Resource costs, which are related with the time that the different members of the project teams have dedicated to the project; business intelligence development costs, which are related with the SBSC implementation; and re-engineering costs, which are related with the investments to change the different business process. 


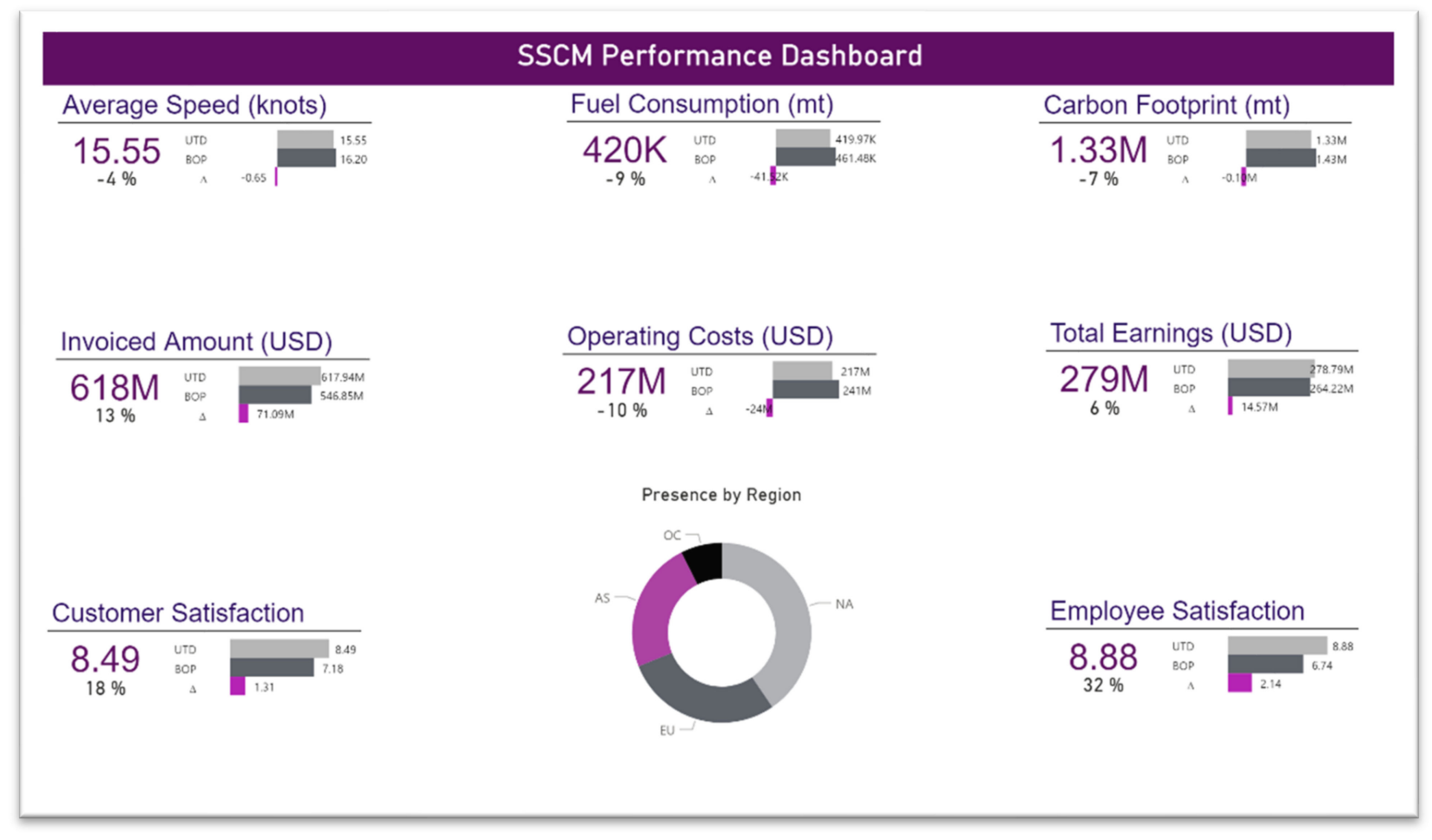

Figure 4. Improvements after the application of the SSCM-IRIS framework.

Validation of collected data. As the data collected were qualitative, they were analyzed using qualitative data methods of analysis. The threats to the validity of the case study were reduced using the Lincoln and Guba model [75], in which five strategies are proposed for use in data collection to tackle three types of threats to validity. The three types of threats considered were reactivity (the researcher's presence can affect the setup of the study), researcher bias (the researcher's preconceived ideas can affect the way the researcher asks questions or interprets answers), and respondent bias (the researcher's influence on the attitude of the people being studied).

\section{Discussion}

\subsection{Theoretical Implications}

In this paper, a framework called SSCM-IRIS is proposed, which facilitates the task of sustainability management in supply chains. The framework has been validated through questionnaires by both academics and practitioners who are experts in supply chains and in enterprise sustainability, and through a case study. Experts highlighted the capacity of the framework to be applied to different kinds of supply chains; the holistic approached adopted; the inclusion of a methodology to guide during all the project life cycle and the level of detail in each phase of the methodology; the structure proposed to organize the SBSC objectives and indicators; the consideration of indicators obtained by the use of Big Data techniques; the proposal of a computer architecture to support the SSCM implementation; and the overall understanding of the project that the framework offers. These positive comments were corroborated by members of the SSCM management team of the company where the SSCM-IRIS framework was applied, who in addition added that the results obtained in the application of the SSCM-IRIS framework to the company were satisfactory, as all the goals set out at the beginning of the project were achieved and the initially established timespan was accomplished without significant deviations.

Therefore, the SSCM-IRIS framework innovates and contributes to the state of the art of the frameworks for supply chain sustainability in the following way:

(1) The proposal of a methodology dimension, which integrates sustainability assessment with sustainability improvement projects. None of the existing frameworks include a method- 
ology to guide during all the activities in the whole Supply Chain Sustainability Management project life cycle, which integrates the assessment of sustainability with the action plans to improve SC sustainability. As a result, big opportunities to make improvements in SC sustainability can be missed [33]. In contrast to existing frameworks, the SSCM-IRIS framework guides during the whole project life explaining all the phases, activities and tasks that should be done and how and by whom, from the SC sustainability strategy definition till the business processes reengineering to improve the SC sustainability.

(2) The combination of qualitative methods for sustainability objectives and strategy planning definition with quantitative methods to assess if all the SC companies meet their goals in all sustainability dimensions and at different levels. As [6] state, the qualitative and quantitative approaches for sustainability assessment are not combined in existing frameworks; therefore, they do not benefit from the advantages of combining both types of assessment.

(3) The SSCM-IRIS framework can be applied to any kind of SC. The majority of existing frameworks are addressed to a specific type of supply chain, usually from the manufacturing industry $[76,77]$, which limits their validity for other supply chains.

(4) The SSCM-IRIS framework adopts a holistic approach through a Sustainability Balanced Scorecard that allows the SC environmental, social, and economic sustainability performance to be analyzed and improved. This is an important lack of existing frameworks that are mainly focused on specific sustainability issues instead of adopting a holistic approach that would enable them to improve all the SC environmental, social, and economic sustainability performance [32].

(5) The SSCM-IRIS framework improves the analysis of the impact of SC sustainability, as well as the SC future impact using Big Data analytics. Unlike existing frameworks that focus on measuring only the past economic, social, or environmental impact of the SC [34,35], the SSCM-IRIS framework provides the design, architecture and software necessary to take advantage of the possibilities that the new technologies, such as Big Data, offer to improve the diagnostic analysis and to carry out a predictive analysis of the future impact of the SC sustainability.

(6) The framework was applied to a case study. This is an important advantage over other existing frameworks because there is a lack of verified Sustainable Supply Chain Management (SSCM) frameworks, which raises a serious question on their applicability and has become a concern for the practitioners [36].

\subsection{Managerial Implications}

This work presents some interesting outcomes which can be helpful for supply chain managers. Firstly, the SSCM-IRIS framework attempts to offer managers a prescriptive model of how to create a sustainable supply chain using Big Data. This can help to avoid the problems that managers have with integrating Big Data and sustainability [78]. Secondly, the framework can support business insights, as it offers a rigorous and serious analysis to translate data into new knowledge. Supply chains managers who want to use insights as the platform for sustainability require a process that is both scalable and repeatable so that it can become routinized within the supply chain with predictable long-term results. Thirdly, the SSCM-IRIS framework highlights the importance of technical skills and managerial skills for creating a sustainable supply chain using Big Data and Balanced Scorecard. The framework offers guidance to human resource managers, policy makers, and Big Data managers on what skills are needed and when and how are they used. Finally, the SSCMIRIS framework makes SSCM easier for the supply chain managers by adding innovative elements to achieve a more efficient management. Thus, the framework allows clarification and updating of the SC sustainability strategy; reconsideration of the sustainability impact of each enterprise in the SC and the SC as a whole; communication of the SC sustainability strategy throughout the SC; alignment of enterprise, departmental, and individual goals 
with the SC sustainability strategy; connection of sustainability objectives to long-term goals and budgets; and recurrent analysis of environmental, social, and economic performance.

\section{Conclusions}

Sustainability Supply Chain Management addresses the integration of the three dimensions of sustainability (economic, social, and environmental) in the making of decisions and the execution of activities along the whole supply chain and beyond its limits. Several frameworks have been proposed to solve these issues. However, existing SSCM frameworks have some weaknesses. For this reason, there has been the need to develop the SSCM-IRIS framework. It is structured in six dimensions: methodology, organization, stakeholders, maturity model, human resources, and technology.

This work has some limitations that can be addressed by future research. On the one hand, although the framework integrates methodologies, methods, techniques, and tools that have been successfully applied in real cases in other fields, the main constraint of the proposed framework is that it has been applied to improve the SSCM in only one real supply chain. Therefore, as a future work, it would be interesting to perform several case studies in supply chains from different market sectors in order to validate and enhance the framework. These case studies could also be useful as reference models and examples of how to apply the framework, which will help in reducing time, costs, and failures in its implementation.

Author Contributions: Conceptualization, R.C. and J.-E.B.-M.; Formal analysis, J.-E.B.-M.; Investigation, J.-E.B.-M.; Methodology, R.C. and J.-E.B.-M.; Project administration, R.C.; Supervision, R.C.; Validation, R.C.; Writing-original draft, R.C. All authors have read and agreed to the published version of the manuscript.

Funding: This research received no external funding.

Institutional Review Board Statement: Not applicable.

Informed Consent Statement: Not applicable.

Conflicts of Interest: The authors declare no conflict of interest.

\section{References}

1. Brundtland, G.H.; Khalid, M.; Agnelli, S.; Al-Athel, S.; Chidzero, B.J.N.Y. Our Common Future: Brundtland Report; ONU: Ada, OH, USA, 1987.

2. Maes, M.J.; Jones, K.; Toledano, M.B.; Milligan, B. Mapping synergies and trade-offs between urban ecosystems and the sustainable development goals. Environ. Sci. Policy 2019, 93, 181-188. [CrossRef]

3. Cortado, F.-J.; Chalmeta, R. Use of social networks as a CSR communication tool. Cogent Bus. Manag. 2016, 3, 1187783. [CrossRef]

4. Thoeni, A.; Tjoa, A. Information technology for sustainable supply chain management: A literature survey. Enterp. Inf. Syst. 2017, 11, 828-858. [CrossRef]

5. Azevedo, S.G.; Carvalho, H.; Duarte, S.; Machado, V. Influence of green and lean upstream supply chain management practices on business sustainability. IEEE Trans. Eng. Manag. 2012, 59, 753-765. [CrossRef]

6. Ansari, Z.N.; Kant, R. Exploring the framework development status for sustainability in supply chain management: A systematic literature synthesis and future research directions. Bus. Strat. Environ. 2017, 26, 873-892. [CrossRef]

7. Mentzer, J.T.; Dewitt, W.; Keebler, J.S.; Min, S.; Nix, N.W.; Smith, C.D.; Zacharia, Z.G. What is supply chain management? In Supply Chain Management; Mentzer, J.T., Ed.; Sage Publications: Thousand Oaks, CA, USA, 2001; pp. 1-25.

8. Lummus, R.R.; Vokurka, R.J. Defining supply chain management: A historical perspective and practical guidelines. Ind. Manag. Data Syst. 1999, 99, 11-17. [CrossRef]

9. Tan, K.C.; Lyman, S.B.; Wisner, J.D. Supply chain management: A strategic perspective. Int. J. Oper. Prod. Manag. 2002, 22, 614-631. [CrossRef]

10. Christiansen, B. Handbook of Research on Global Supply Chain Management; IGI Global: Battle Creek, MI, USA, 2015.

11. Fawcett, S.E.; Magnan, G.M.; McCarter, M.W. Benefits, barriers, and bridges to effective supply chain management. Supply Chain Manag. Int. J. 2008, 13, 35-48. [CrossRef]

12. Elkington, J. Cannibals with Forks: The Triple Bottom Line of 21st Century Business; Capstone: Oxford, UK, 1997.

13. Bastas, A.; Liyanage, K. Integrated quality and supply chain management business diagnostics for organizational sustainability improvement. Sustain. Prod. Consum. 2019, 17, 11-30. [CrossRef] 
14. Ramezankhani, M.; Torabi, S.A.; Vahidi, F. Supply chain performance measurement and evaluation: A mixed sustainability and resilience approach. Comput. Ind. Eng. 2018, 126, 531-548. [CrossRef]

15. Min, H.; Kim, I. Green supply chain research: Past, present, and future. Logist. Res. 2012, 4, 39-47. [CrossRef]

16. Kamali, F.P.; Borges, J.A.R.; Osseweijer, P.; Posada, J.A. Towards social sustainability: Screening potential social and governance issues for biojet fuel supply chains in Brazil. Renew. Sustain. Energy Rev. 2018, 92, 50-61. [CrossRef]

17. Chen, L.; Zhao, X.; Tang, O.; Price, L.; Zhang, S.; Zhu, W. Supply chain collaboration for sustainability: A literature review and future research agenda. Int. J. Prod. Econ. 2017, 194, 73-87. [CrossRef]

18. Saputri, V.H.L.; Sutopo, W.; Hisjam, M.; Ma'Aram, A. Sustainable agri-food supply chain performance measurement model for GMO and Non-GMO using data envelopment analysis method. Appl. Sci. 2019, 9, 1199. [CrossRef]

19. Hussain, M.; Ajmal, M.M.; Gunasekaran, A.; Khan, M. Exploration of social sustainability in healthcare supply chain. J. Clean. Prod. 2018, 203, 977-989. [CrossRef]

20. Ashby, A.L.; Leat, M.; Smith, M. Making connections: A review of supply chain management and sustainability literature. Supply Chain Manag. Int. J. 2012, 17, 497-516. [CrossRef]

21. Ha-Brookshire, J. Toward moral responsibility theories of corporate sustainability and sustainable supply chain. J. Bus. Ethic. 2017, 145, 227-237. [CrossRef]

22. Gold, S.; Schleper, M.C. A pathway towards true sustainability: A recognition foundation of sustainable supply chain management. Eur. Manag. J. 2017, 35, 425-429. [CrossRef]

23. Seuring, S.; Sarkis, J.; Müller, M.; Rao, P. Sustainability and supply chain management-An introduction to the special issue. J. Clean. Prod. 2008, 16, 1545-1551. [CrossRef]

24. Chowdhury, M.H.; Agarwal, R.; Quaddus, M. Dynamic capabilities for meeting stakeholders' sustainability requirements in supply chain. J. Clean. Prod. 2019, 215, 34-45. [CrossRef]

25. Reefke, H.; Sundaram, D. Key themes and research opportunities in sustainable supply chain management-Identification and evaluation. Omega 2017, 66, 195-211. [CrossRef]

26. Gharaei, A.; Karimi, M.; Shekarabi, S.A.H. An integrated multi-product, multi-buyer supply chain under penalty, green, and quality control polices and a vendor managed inventory with consignment stock agreement: The outer approximation with equality relaxation and augmented penalty algorithm. Appl. Math. Model. 2019, 69, 223-254. [CrossRef]

27. Yuqiuge, H.; Petri, H.; Ahm, S. Virtual factory system design and implementation: Integrated sustainable manufacturing. Int. J. Syst. Sci. 2018, 5, 116-132.

28. Izadikhah, M.; Saen, R.F. Assessing sustainability of supply chains by chance-constrained two-stage DEA model in the presence of undesirable factors. Comput. Oper. Res. 2017, 100, 343-367. [CrossRef]

29. Tajbakhsh, A.; Hassini, E. A data envelopment analysis approach to evaluate sustainability in supply chain networks. J. Clean. Prod. 2015, 105, 74-85. [CrossRef]

30. Muñoz-Torres, M.J.; Fernández-Izquierdo, M.Á.; Rivera-Lirio, J.M.; Ferrero-Ferrero, I.; Escrig-Olmedo, E.; Gisbert-Navarro, J.V.; Marullo, M.C. An assessment tool to integrate sustainability principles into the global supply chain. Sustainability 2018, 10, 535. [CrossRef]

31. Pawlowski, J.; Bick, M. The global knowledge management framework: Towards a theory for knowledge management in globally distributed settings. Electron. J. Knowl. Manag. 2012, 10, 92-108.

32. Elhidaoui, S.; Benhida, K.; Benhida, K.; Elfezazi, S.; El Hachadi, A. Environmental dimension in sustainable supply chain management. Framework and literature review. Int. J. Adv. Appl. Sci. 2020, 7, 74-90.

33. Wollmuth, J.; Ivanova, V. 6 Steps for a More Sustainable Supply Chain. 2014. Available online: https://www.greenbiz.com/blog/ 2014/01/24/6-steps-more-sustainable-supply-chain (accessed on 14 June 2021).

34. Bag, S.; Wood, L.C.; Xu, L.; Dhamija, P.; Kayikci, Y. Big data analytics as an operational excellence approach to enhance sustainable supply chain performance. Resour. Conserv. Recycl. 2020, 153, 104559. [CrossRef]

35. Kaur, H.; Singh, S.P. Heuristic modeling for sustainable procurement and logistics in a supply chain using big data. Comput. Oper. Res. 2018, 98, 301-321. [CrossRef]

36. Yadav, G.; Luthra, S.; Jakhar, S.K.; Mangla, S.K.; Rai, D.P. A framework to overcome sustainable supply chain challenges through solution measures of industry 4.0 and circular economy: An automotive case. J. Clean. Prod. 2020, 254, 120112. [CrossRef]

37. Saggi, M.K.; Jain, S. A survey towards an integration of big data analytics to big insights for value-creation. Inf. Process. Manag. 2018, 54, 758-790. [CrossRef]

38. Adams, M.N. Perspectives on data mining. Int. J. Mark. Res. 2010, 52, 11-19. [CrossRef]

39. Gao, Q.; Guo, S.; Liu, X.; Manogaran, G.; Chilamkurti, N.; Kadry, S. Simulation analysis of supply chain risk management system based on IoT information platform. Enterp. Inf. Syst. 2020, 14, 1354-1378. [CrossRef]

40. Mani, V.; Gunasekaran, A.; Delgado, C. Enhancing supply chain performance through supplier social sustainability: An emerging economy perspective. Int. J. Prod. Econ. 2018, 195, 259-272. [CrossRef]

41. Marjani, M.; Nasaruddin, F.H.; Gani, A.; Karim, A.; Hashem, I.A.T.; Siddiqa, A.; Yaqoob, I. Big IoT data analytics: Architecture, opportunities, and open research challenges. IEEE Access 2017, 5, 5247-5261. [CrossRef]

42. Mahmood, A.; Zen, H.; Hilles, S.M.S. Big data and privacy issues for connected vehicles in intelligent transportation systems. In Encyclopedia of Big Data Technologies; Sakr, S., Zomaya, A., Eds.; Springer: Cham, Switzerland, 2018.

43. Olshannikova, E.; Olsson, T.; Huhtamäki, J.; Kärkkäinen, H. Conceptualizing big social data. J. Big Data 2017, 4, 3. [CrossRef] 
44. Mamonov, S.; Triantoro, T.M. The strategic value of data resources in emergent industries. Int. J. Inf. Manag. 2018, 39, 146-155. [CrossRef]

45. Hazen, B.T.; Skipper, J.B.; Ezell, J.D.; Boone, C.A. Big data and predictive analytics for supply chain sustainability: A theory-driven research agenda. Comput. Ind. Eng. 2016, 101, 592-598. [CrossRef]

46. Wadmann, S.; Hoeyer, K. Dangers of the digital fit: Rethinking seamlessness and social sustainability in data-intensive healthcare. Big Data Soc. 2018, 5. [CrossRef]

47. Raut, R.D.; Mangla, S.K.; Narwane, V.S.; Gardas, B.B.; Priyadarshinee, P.; Narkhede, B.E. Linking big data analytics and operational sustainability practices for sustainable business management. J. Clean. Prod. 2019, 224, 10-24. [CrossRef]

48. Bibby, L.; Dehe, B. Defining and assessing industry 4.0 maturity levels-Case of the defence sector. Prod. Plan. Control. 2018, 29, 1030-1043. [CrossRef]

49. Waller, M.A.; Fawcett, S.E. Data science, predictive analytics, and big data: A revolution that will transform supply chain design and management. J. Bus. Logist. 2013, 34, 77-84. [CrossRef]

50. Dubey, R.; Gunasekaran, A.; Papadopoulos, T.; Childe, S.J.; Shibin, K.; Wamba, S.F. Sustainable supply chain management: Framework and further research directions. J. Clean. Prod. 2017, 142, 1119-1130. [CrossRef]

51. Gunasekaran, A.; Papadopoulos, T.; Dubey, R.; Wamba, S.F.; Childe, S.J.; Hazen, B.; Akter, S. Big data and predictive analytics for supply chain and organizational performance. J. Bus. Res. 2017, 70, 308-317. [CrossRef]

52. Papadopoulos, T.; Gunasekaran, A.; Dubey, R.; Altay, N.; Childe, S.J.; Fosso-Wamba, S. The role of big data in explaining disaster resilience in supply chains for sustainability. J. Clean. Prod. 2017, 142, 1108-1118. [CrossRef]

53. De, A.; Wang, J.; Tiwari, M. Hybridizing basic variable neighbourhood search with particle swarm optimization for solving sustainable ship routing and bunker management problem. IEEE Trans. Intell. Transp. Syst. 2019, 21, 986-997. [CrossRef]

54. De, A.; Choudhary, A.; Tiwari, M.K. Multiobjective approach for sustainable ship routing and scheduling with draft restrictions IEEE Trans. Eng. Manag. 2019, 66, 35-51. [CrossRef]

55. Chen, L.; Jia, G. Environmental efficiency analysis of China's regional industry: A data envelopment analysis (DEA) based approach. J. Clean. Prod. 2017, 142, 846-853. [CrossRef]

56. Wu, L.; Yue, X.; Jin, A.; Yen, D.C. Smart supply chain management: A review and implications for future research. Int. J. Logist. Manag. 2016, 27, 395-417. [CrossRef]

57. Ramadan, M.; Shuqqo, H.; Qtaishat, L.; Asmar, H.; Salah, B. Sustainable competitive advantage driven by big data analytics and innovation. Appl. Sci. 2020, 10, 6784. [CrossRef]

58. Mani, V.; Delgado, C.; Hazen, B.T.; Patel, P. Mitigating supply chain risk via sustainability using big data analytics: Evidence from the manufacturing supply chain. Sustainability 2017, 9, 608. [CrossRef]

59. Cheng, T.C.E.; Kamble, S.S.; Belhadi, A.; Ndubisi, N.O.; Lai, K.-H.; Kharat, M.G. Linkages between big data analytics, circular economy, sustainable supply chain flexibility, and sustainable performance in manufacturing firms. Int. J. Prod. Res. 2021, 1-15. [CrossRef]

60. Chalmeta, R.; Santos-Deleón, N.J. Sustainable supply chain in the era of industry 4.0 and big data: A systematic analysis of literature and research. Sustainability 2020, 12, 4108. [CrossRef]

61. Lukman, R.; Glavič, P. What are the key elements of a sustainable university? Clean Technol. Environ. Policy 2006, 9, 103-114. [CrossRef]

62. Holmberg, J.; Larsson, J. A sustainability lighthouse-Supporting transition leadership and conversations on desirable futures. Sustainability 2018, 10, 3842. [CrossRef]

63. Orenga-Roglá, S.; Chalmeta, R. Framework for implementing a big data ecosystem in organizations. Commun. ACM 2019, 62, 58-65. [CrossRef]

64. Chalmeta, R.; Palomero, S. Methodological proposal for business sustainability management by means of the Balanced Scorecard. J. Oper. Res. Soc. 2011, 62, 1344-1356. [CrossRef]

65. Fobbe, L. Analysing organisational collaboration practices for sustainability. Sustainability 2020, 12, 2466. [CrossRef]

66. Ahern, M.; Clouse, A.; Turner, R. CMMI Distilled: A Practical Introduction to Integrated Process Improvement; SEI; Addison Wesley: Boston, MA, USA, 2004.

67. Dos Santos-Neto, J.B.S.; Costa, A.P.C.S. Enterprise maturity models: A systematic literature review. Enterp. Inf. Syst. 2019, 13, 719-769. [CrossRef]

68. Figge, F.; Hahn, T.; Schaltegger, S.; Wagner, M. The sustainability balanced scorecard—Linking sustainability management to business strategy. Bus. Strat. Environ. 2002, 11, 269-284. [CrossRef]

69. Kaplan, R.; Norton, D. Translating Strategy into Action: The Balanced Scorecard; Harvard Business School Press: Boston, MA, USA, 1996.

70. Díaz-Curbelo, A.; Gento, Á.M.; Redondo, A.; Aqlan, F. A fuzzy-based holistic approach for supply chain risk assessment and aggregation considering risk interdependencies. Appl. Sci. 2019, 9, 5329. [CrossRef]

71. Palomero, S.; Chalmeta, R. A guide for supply chain integration in SMEs. Prod. Plan. Control. 2012, 25, 372-400. [CrossRef]

72. Azevedo, S.G.; Carvalho, H.; Ferreira, L.; Matias, J. A proposed framework to assess upstream supply chain sustainability. Environ. Dev. Sustain. 2017, 19, 2253-2273. [CrossRef]

73. Alkahtani, M.; Choudhary, A.; De, A.; Harding, J.A. A decision support system based on ontology and data mining to improve design using warranty data. Comput. Ind. Eng. 2019, 128, 1027-1039. [CrossRef] 
74. Runeson, P.; Höst, M. Guidelines for conducting and reporting case study research in software engineering. Empir. Softw. Eng. 2009, 14, 131-164. [CrossRef]

75. Robson, C. Real World Research; Blackwell Publishers: Oxford, UK, 2002.

76. Wang, M.; Wang, B.; Abareshi, A. Blockchain technology and its role in enhancing supply chain integration capability and reducing carbon emission: A conceptual framework. Sustainability 2020, 12, 550. [CrossRef]

77. Junaid, M.; Xue, Y.; Syed, M.W.; Li, J.Z.; Ziaullah, M. A neutrosophic AHP and TOPSIS framework for supply chain risk assessment in automotive industry of Pakistan. Sustainability 2020, 12, 154. [CrossRef]

78. Scholz, R.W. Sustainable digital environments: What major challenges is humankind facing? Sustainability 2018, 8, 726. [CrossRef] 